\title{
ANOMALOUS CHLORINE CONTENTS OF MIOCENE GRANITOIDS FROM TSUSHIMA, JAPAN
}

\author{
Shigere Terashima and Shunso Ishimara \\ Geological Survey of Japan, Higashi 1-1-3, Yatabe, Tsukuba, Ibaraki, Japan
}

\begin{abstract}
Miocene granite and granodiorite of Tsuslima islands contain 700 to $1,400 \mathrm{ppm} \mathrm{Cl}$ in general, which are higher in one order of magnitude than chlorine contents of common granitoids in Japan. The Miocene yranitoids belong to so-called calc-alkaline series but slightly potassic, and contain no Cl-minerals. The main cause for the anomalous values seems to be chlorine trapped in fluid inclusions contained in various rock-forming minerals. Ratios of cilorine contained in fuid inclusions and rock-forming minerals appear to increase with increasing silica contents. This Cl-enrichment in aqueous phase during the magmatic fractionation as well as original high content may have played an impartant role for lead-zinc mineralization of the Taishn mine.
\end{abstract}

\section{INTRODUCTION}

Japanese granitoids contain generally 100 to $200 \mathrm{ppm} \mathrm{Cl}$. The average contents for those from non-metamorphic terrains for example, vary from $137 \mathrm{ppm}(\mathrm{n}=60)$ of the San'in belt to $187 \mathrm{ppm}(\mathrm{n}=48)$ of the Kitakami and Abukuma belts (Ishihara and Terashima, 1977). However the reconnaissance study has shown that Miocene granites from Tsushima islands are very rich in chlorine, ranging from 600 to 960 pprn. The samples used for that study are obtained from satellitic small masses around the main granitic stock. Thus additional sampling was made on the main, central mass, and the samples collected were analzyed for $\mathrm{Cl}$ and $\mathrm{F}$ and major elements in order to clarify petrochemical character of the Miocene granitoids.

The samples are so-called fresh rocks available on surface. They were washed by water and crushed under 130 mesh. Chlorine and fluorine were analyzed by a spectrophotometric method (Terashima, 1974). The other elements were analyzed by the ways described in Terashima $(1978,1979)$.

\section{General ReMarks}

Tsushima consists of North and South islands. The granitoids occur in the South island as small stocks, less than $5 \mathrm{~km}$ in diameter (Fig. 1), but a large hidden mass is assumed for presence of satellitic masses around the main mass and thermal aureole recorded in the roof sedimentary rocks. The hidden mass may even be present in the North island according to drill core study (Metallic Mining Agency of Japan, 1974).

The granitoids have Miocene age (12 Ma, Kawano and Ueda, 1966), low Sr initial ratio (0.7037, Shibata and Ishihara, 1979) and high $\delta^{84} \mathrm{~S}$ rock sulfur $+2.5 \%$, Sasaki and Ishihara, 1979). They intrude into Taishu formation of Oligocene-Miocene-age, which consists of sandstone, shale and inter- 


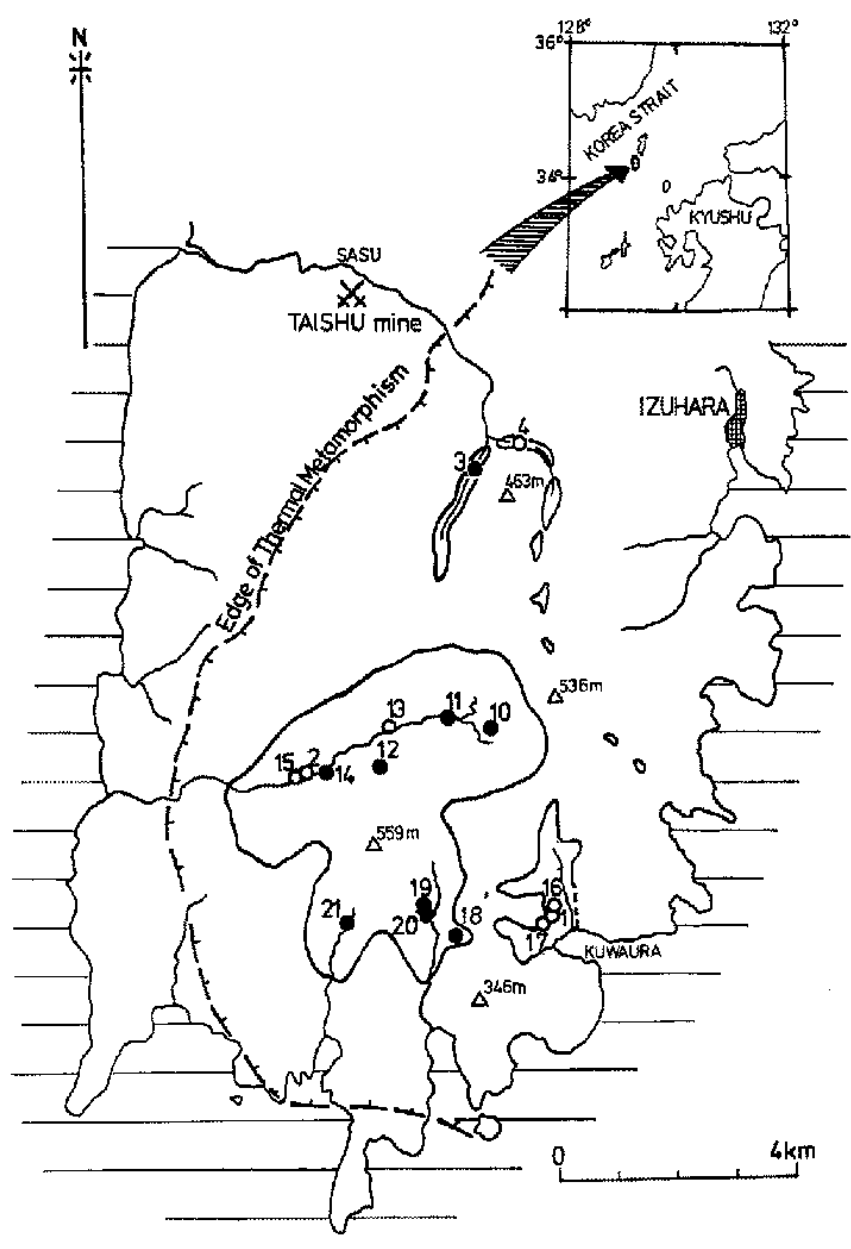

Fig. 1 Distribution of the Miocene granitoids and locality of the analyzed samples in the South island, Tsushima. Geological information is taken from data provided by the Taishu mine. Solid circle, the magmetite-series and opon circle, the ilmenite-series of Ishihara (1977).

calated silicic volcanic rocks. This formation is tightly folded; the granitoids occur in one of the anticlinal axes. Lead-zinc veins of the Taishu mine are distributed in the northnorthwestern flank of the granitic masses.

The granitoids are generally fine-grained monzogranite and granodiorite. Biotite is universal mafic silicate; hornblende is common in the granodiorite. Magnetite is present in general, but absent in the satallitic masses where interaction of the gra- nitoids with country rocks is evident. pyrrhotite and graphite-like mineral are seen in some of the magnetite-free granitoids.

Pyrite is abundant locally. Thus, the Miocene granitoids belong essentially to the magnetite-series of Ishihara (1977) (see also Fig. 1).

\section{Analytical Results}

All the rocks collected were analyzed for $\mathrm{Cl}$ and $\mathrm{F}$, and also $\mathrm{P}_{2} \mathrm{O}_{5}$. The results are 
Table 1 List of the analzyed samples and results of $\mathrm{P}_{2} \mathrm{O}_{5}, \mathrm{Cl}$ and $\mathrm{F}$ analyses

\begin{tabular}{|c|c|c|c|c|c|}
\hline Sample No & Sample description & $P_{2} 0_{5}\{z\rangle$ & $\mathrm{Cl}$ (ppsi) & $\mathrm{F}(\mathrm{ppm})$ & $x\left(x>0^{-6}\right.$, eruu $\left./ g\right)$ \\
\hline \multicolumn{6}{|c|}{ Central msss } \\
\hline$\underline{\mathrm{II}-10}$ & Fine-gratned, biot1te-amphibole granodiort te & 0.28 & 1385 & 590 & 1056 \\
\hline$\underline{I I-20 A}$ & Fina-gratred, amphitrola-biotite granodiorite & 0.22 & 1220 & 400 & 309 \\
\hline$I I-20 B$ & Mediurm grained, amphtbole-biotita granodiort te & 0.22 & 1420 & 520 & 679 \\
\hline$T I-2\} A$ & ditto & 0.15 & 1400 & 420 & $52 ?$ \\
\hline$\underline{t[-i]}$ & Medium-grained, amphrboie-bearing blotite gyanodiorite & 0.14 & 1160 & 580 & 870 \\
\hline II-15 & Medf um-grained, (amphibo) is-bearing) biatite granodiorite & 0,14 & 1340 & 550 & 35 \\
\hline $\operatorname{TI} 19 A$ & Fine urained, bintite granodforite & 0.14 & 11,90 & 350 & 68 \\
\hline$\pi-19$ & F1ne-grayned, (amphibolexbearing\} blotite monzogranite & 0.07 & 890 & 190 & 602 \\
\hline$I I-12$ & Medium grained, biotite monzograntite & 0.02 & 1130 & 280 & 37 \\
\hline$T 1-13$ & ditto & 0.03 & 715 & 500 & 23 \\
\hline$I Y-14 A$ & dit to & 0.04 & 845 & 460 & 279 \\
\hline$\pi r-2$ & Fine-grained biotite monacgranite & 0.03 & 710 & 310 & 34 \\
\hline $\mathrm{Tl}-14 \mathrm{~B}$ & ditto* & 0.04 & 975 & 300 & 19 \\
\hline \multicolumn{6}{|c|}{ Southeastern mass } \\
\hline$[1-17$ & Modium-gralned, biotite granodiorite & 0.25 & 4400 & 1010 & 44 \\
\hline$T I-16 \mathrm{~A}$ & Coarse-grained, biotite grenscilorite* & 0.04 & 1125 & 480 & 23 \\
\hline $\mathrm{TI}=16 \mathrm{~g}$ & Fine-grained, biotite monzogranite & 0.05 & 920 & 440 & 27 \\
\hline 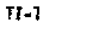 & ditto & 0.05 & 930 & 540 & 12 \\
\hline \multicolumn{6}{|c|}{ Northern mass } \\
\hline$T S-4$ & Coarse-grained, biatite granodforite & 0.12 & 960 & 830 & 21 \\
\hline$T I-3$ & Hedhummgrafned, Diotite monzogränite & $0.0 E$ & 600 & 670 & $2 \mathrm{Eg}$ \\
\hline
\end{tabular}

* Feldspars slightly argilitized

$x$, Magnetic susceptibility measurad by H. KAHAYA

Underlined sampie numbers are those listed in Table 2

Table 2 Major chemistry of selectcd samples from the central mass and southeastern mass (TI-17). Analytical methods for major components are described in Terashima (1979). Sulfur and total carbon by infrared absorption spectroscopy (Terashima: 1978).

\begin{tabular}{|c|c|c|c|c|c|c|c|c|c|}
\hline & TI-17 & $T I-10$ & $71-206$ & $\mathrm{Tt}-20 \mathrm{~A}$ & $\mathrm{II} \cdot \mathrm{II}$ & $\mathrm{II}-1 \mathrm{~B}$ & II-19 & $\mathrm{rI}-14 \mathrm{~A}$ & $\mathrm{TI}-12$ \\
\hline $\mathrm{SiO}_{2}$ & 61.61 & 61.91 & 69.76 & 66.41 & 68.29 & 68.55 & 73,23 & 75.02 & 75.94 \\
\hline $\mathrm{THO}_{2}$ & 0.90 & 1.21 & 0.76 & 0.63 & 0.57 & 0.59 & 0.28 & 0.22 & 0.16 \\
\hline $\mathrm{Al}_{2} \mathrm{O}_{3}$ & 15.30 & 35.23 & 15.88 & 15.85 & 14.92 & 14.38 & 33.31 & 13.02 & 12.71 \\
\hline $\mathrm{Fe}_{2} \mathrm{O}_{3}$ & 1.52 & 2.36 & 1.88 & 1.43 & 1.97 & 1.07 & 1.45 & 1.79 & 0.70 \\
\hline $\mathrm{FeO}$ & 6.87 & 4.83 & 4.03 & 3.24 & 2.69 & 3.31 & 1.45 & 0.91 & 0.84 \\
\hline $\mathrm{M} \cap \mathrm{D}$ & 0.041 & 0.104 & 0.036 & 0.027 & 0.043 & 0.075 & 0.015 & 0.023 & 0.015 \\
\hline $\mathrm{MgO}$ & 2.71 & 2.12 & 1.52 & 1.20 & 0.98 & 1.10 & 0.47 & 0.32 & 0.26 \\
\hline$C a 0$ & 3.20 & 5.75 & 4.20 & 3.61 & 3,10 & 2,56 & 2.00 & 7.34 & 1.32 \\
\hline $\mathrm{Na}_{2} \mathrm{O}$ & 3,48 & 3.40 & 3.44 & 3.95 & 3.66 & 2.96 & 2.98 & 3.18 & 3.06 \\
\hline$K_{2} O$ & 3.03 & 2.16 & 3.07 & 2.93 & 3.25 & 4,08 & 4.30 & 4.31 & 4.47 \\
\hline$P_{205}$ & 0.25 & 0.26 & 0.22 & 0.22 & 0.14 & 0.14 & 0.07 & 0.04 & 0.02 \\
\hline 5 & 0.068 & 0.034 & 0.032 & 0.045 & 0.004 & 0.636 & 0.005 & 0.003 & 0.003 \\
\hline c & 0.005 & 0.012 & 0.006 & 0.005 & 0.007 & 0.002 & 0.003 & 0.003 & 0.004 \\
\hline $\mathrm{H}_{2} \mathrm{O}(+)$ & 0.80 & 0.46 & 0.58 & 0.45 & 0.34 & 0,48 & 0.38 & 0,36 & 0.39 \\
\hline $\mathrm{H}_{2} \mathrm{O}\{\mathrm{m}\}$ & 0.11 & 0.03 & 0.07 & 0.05 & 0.02 & 0.07 & 0.03 & $0.0 B$ & 0.09 \\
\hline Tota1 & 99.89 & 99.89 & 99.88 & 300,06 & 99.98 & 99.94 & 99.97 & 100.02 & 99.98 \\
\hline
\end{tabular}


listed in Table 1. Chlorine varies generally from $1400 \mathrm{ppm}$ to $600 \mathrm{ppm}$, which confirms the results of the previous reconnaissance study. Unusually high value, $4400 \mathrm{ppm}$, was found in granodiorite from the southeastern satellitic mass. Content of chlorine is more than that of fluorine, which is also unusual as compared with the other granitoids in Japan (see Ishihara and Terashima, 1977).

In Table 1, the samples are listed in the order of their color index obtained in the field work. In the main mass, content of chlorine decreases slightly, from 1400 ppm to $700 \mathrm{ppm}$, with decreasing the color index. However, the phosphorus content decreases in the order of magnitude from granodiorite to monzogranite.

Chlorine minerals are known to occur in alkaline granites, so that nine samples were selected for major chemical analysis, in order to identify the rock-series of these granitoids. The results are given in Table 2.

The analyzed samples have silica. contents from 62 to 76 percent and normative feldspar ratios of granodiorite and monzogranite. As compared with the average composition of the Japanese granitoids (Aramaki et al., 1972), the Miocene granitoids are about 1 percent rich in $\mathrm{K}_{2} \mathrm{O}$, but the silica and sodium are close to the averages (Fig. 2). Thus the granitoids are so different from rocks to be called alkalineseries, but belong to normal calc-alkaline series granitoids slightly potassic.

As to the femic components, the Miocene granitoids are characterized by abundance of the total iron. Contents of both $\mathrm{Fe}_{2} \mathrm{O}_{3}$ and $\mathrm{FeO}$ are higher than those of the Japanese average (Fig. 3). Titanium is also higher than the average. The unusually high chlorine rock of TI-17 is unique in its

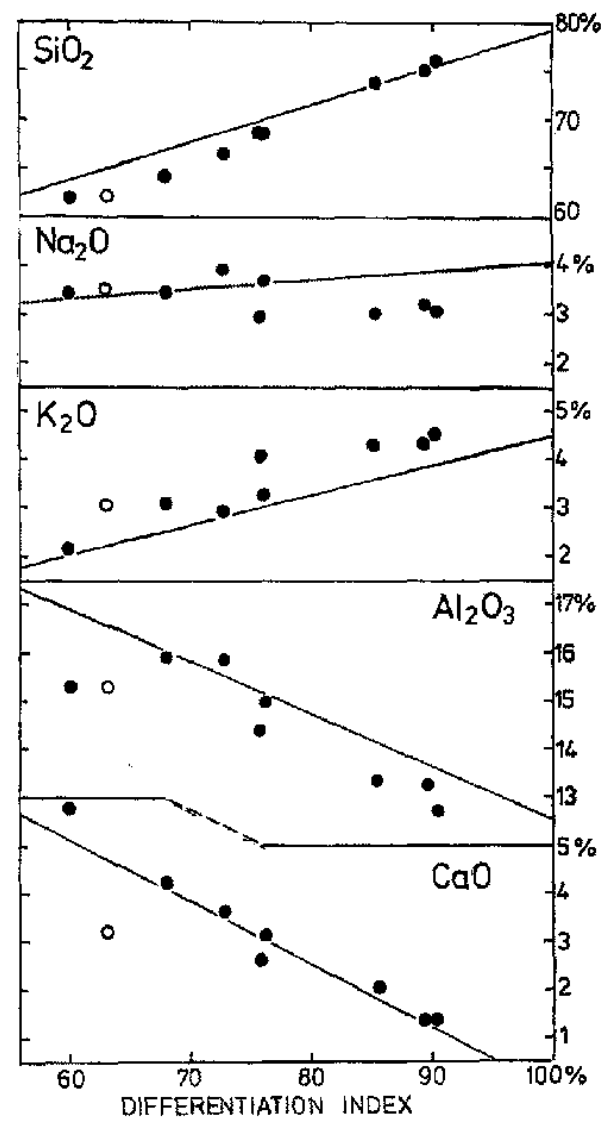

Fig. 2 Salic components plotted against the differentiation index. Solid circle, samples from the central mass; open circle, those from the southeastern mass; straight line, the Japanese average.

high contents of $\mathrm{FeO}$ and $\mathrm{MgO}$ but low contents of $\mathrm{Al}_{2} \mathrm{O}_{3}$ and $\mathrm{CaO}$.

\section{Discussion}

Among common rock-forming minerals of calc-alkaline series rocks, apatite and biotite may be a major carrier of chlorine. As compared with a wide variation in content of phosphorous and ferromagnesian components, however, change of chlorine contents is small indicating some other source for chlorine. Nedachi (1980), indeed, 


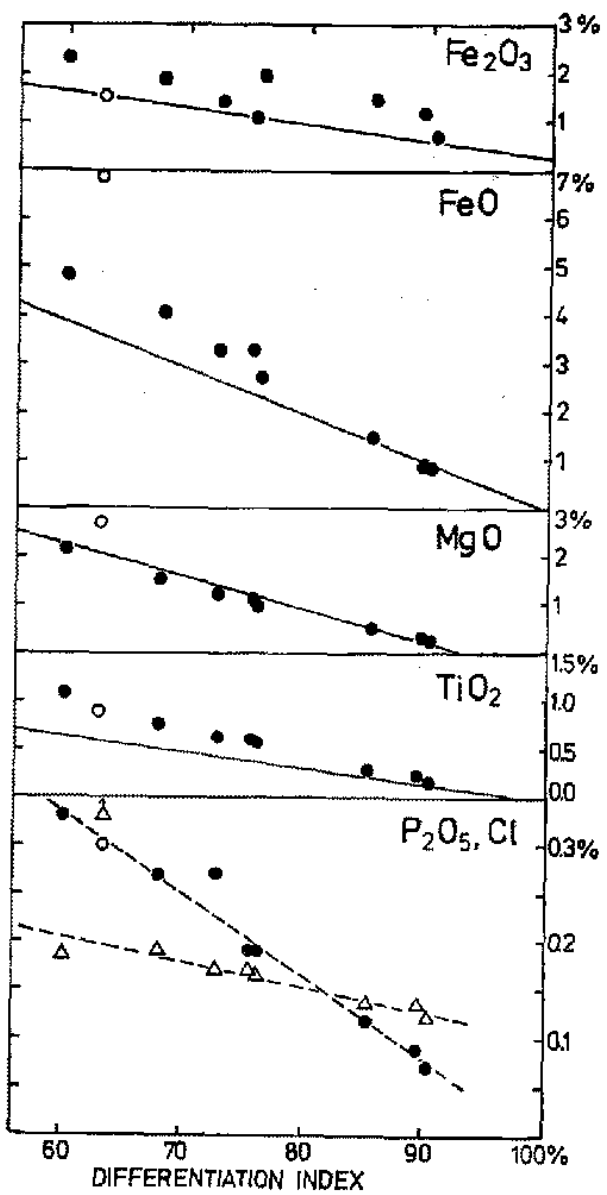

Fig. 3 Femic components plotted against the differentiation index. Circle and line designation, see Fig. 2. In $\mathrm{P}_{2} \mathrm{O}_{5}$ and $\mathrm{Cl}$ section, $\mathrm{Cl}$ is shown by triangle. Broken lines are general trend of $\mathrm{P}_{2} \mathrm{O}_{5}$ and $\mathrm{Cl}$ of the Miocene granitoids.

studied these minerals and found that chlorine contents of apatite and biotite are around 0.3 and 0.06 percent, respectively.

Poly-phase inclusions have been found in quartz of the Miocene granitoids of the northern satellitic group (Imai et al., 1971). Preliminary study by S. Takenouchi on our samples indicate that the poly-phaseinclusions are abundant in rocks having high chlorince contents of the main mass (person- al communication, 1978). Thus, the highly saline inclusions (up to ca. $60 \mathrm{wt} . \%, \mathrm{NaCl}$ Imai et al., 1971), either in quartz or other rock-forming minerals, could be a major cause for the anomalous chlorine values of the Miocene granitoids. The poly-phase inclusions are seen even in granodiorite. The Miocene granitoids seem to have had originally high chlorine content.

As is shown in Figure 3, ratios of $\mathrm{Cl}$ $\mathrm{P}_{2} \mathrm{O}_{5}$ and $\mathrm{Cl} /$ ferromagnesian components are higher in the rocks of high DI range than those of low DI range. This observation may indicate that aqueous phase of the well differentiated granites, as compared that of granodiorite, is very enriched in chlorine, which agrees with the general understanding on behaviour of chlorine in magmatic differentiation (Kiline and Burnham, 1972; Fuge, 1977; Burnham and Ohrnoto, 1980). This highly saline fluid may have been attributed to lead-zinc mineralization at Taishu, as concluded by Imai et al. (1971).

\section{ACKNOWLEDGEMENT}

The writers are most grateful to Professor S. Takenouchi, University of Tokyo, for providing us data of the microscopic observation on fluid inclusions. Thanks are also due to Mr. H. Kanaya, Geological Survey of Japan, for measurement of magnetic susceptibility and the Toho Zinc Company for providing geological information.

\section{REFERENCES}

Aramaki, S., Hirayama, K. and Nozawa, T. (1972) Chemical composition of Japanese granites, Part 2. Variation trends and average composition of 1,200 analyses. Jour. Geol. Soc. Japan, 78, $39-49$

Burnbam, C.W. and Ohmoto, H. (1980) Late-stage 
processes of flesic magmatism, In Granitic magmatism and Related Mineralization Mining Geol. Spec. Issue, 8, (in press)

Fuge, R. (1977) On the behaviour of fluorine and chlorine during magmatic differentiation. Contrib. Mineral. Petrol., 61, 245-249

Imai, H., Takenouchi, S. and Kihara, T. (1971) Fluid inclusion study at the Taishu mine, Japari, as related to geologic structure. Sor. Mining Geol. Japan, Spec, Issue, 3, 321-326

Ishihara, S. (1977) The magnetite-series and i)menite-series granitic rocks, Mining Geol. 27, 293-305

Ishihara, S. and Terashima, S. (1977) Chlorine and fluorine contents of granitoids as indicators for base metal and tin mineralizations. Mining Geol., 27, 191-199 (text in Japanese)

Kawano, Y. and Ueda, Y. (1966) K-A cating on the igenous rocks in Japan - Granitic rocks in southwestern Japan. Jour. Japan. A ssoc. Petr. Min. Econ. Geol., 56, 191-211 (text in Japan. ese)

Kilinc, L.A. and Burnham, C.W. (1972) Partitioning of chloride between a silicate melt and coexisting aqueous phase from 2 to 8 kilobars. Econ. Geol., 67, 231-235

Metallic Mining Agency of Japan (1974) Report of regional geological study, 1974 fiscal year. Tsushima-Agata area, 21p. (in Japanese)

Neđachi, M. (1980) Chlorine and fluorine contents of rock-forming minerals of the Neogene granitic rocks in Kyushu, Japan. In Granitic Magmatism and Related Mineralization. Mining Geol. Spec. Issue, 8 (in press)

Sasaki, A, and Ishihara, S. (1979) Sulfur 1sotopic composition of the magnetite-series and ilmenite-series granitoids in Japan. Contrib. Mineral. Petral., 68, 107-115

Shibata, K. and Ishihara, S. (1979) Initial ${ }^{87} \mathrm{Sr} 7^{80} \mathrm{Sr}$ ratios of the plutonic rocks from Japan. Contrib. Minesal. Petvol., 70, 381-390

Terashima, S. (1974) Spectrophotometric determination of chlorine and fluorine in the standard silicate rocks. Bull. Geol. Surv. Japan, 25, 175 -179

Terashima, S. (1978) The rapid determination of total carbon and sulfur in geological materials by combustion and infrared absorption photometry. Analytica Chimica Acta, 101, 25-31

Terashima, S. (1979) The determination of major and minor elements on the two geochemical reference samples, JA-1 and JB-2, and six geochemical exploration reference samples. Bull. Geol. Surv. Japan, 30, 37-43

\section{対馬鷹花崗岩類中の異常な塩素含有量}

\section{寺島 滋, 石原 舜三}

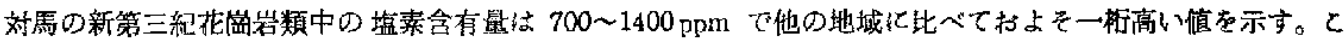

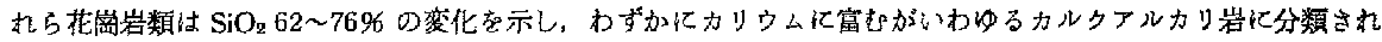

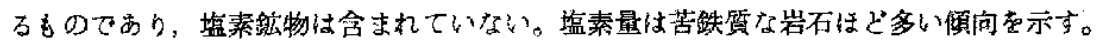

$\mathrm{S}_{2} \mathrm{O}_{2}$ 亿対方る $\mathrm{P}_{2} \mathrm{O}_{5}, \mathrm{FeO}+\mathrm{MgO}, \mathrm{Cl}$ の相関性，鏡下にみられる流体包有物などから，岩石中の塩素は主とし

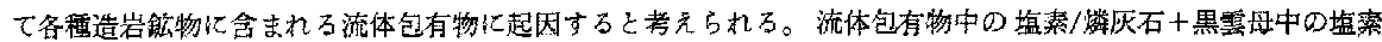

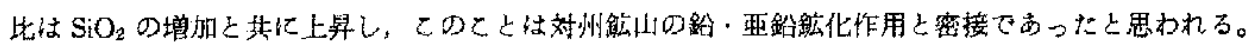

